\begin{tabular}{|c|l|}
\hline Title & A New In Vitro Ovulation Model for Medaka Based on Whole Ovary Culture \\
\hline Author(s) & Ogiwara, Katsueki; Ikeda, Takashi; Takahashi, Takay uki \\
\hline Citation & $\begin{array}{l}\text { Zoological Science, 27(9), 762-767 } \\
\text { https://doi.org/L0.2108/2si.27.762 }\end{array}$ \\
\hline Issue Date & 2010-09 \\
\hline Doc URL & http://hdl.handle.net/2115/49229 \\
\hline Type & article \\
\hline File Information & zsi.27.pdf \\
\hline
\end{tabular}

Instructions for use 


\section{A New In Vitro Ovulation Model for Medaka Based on Whole Ovary Culture}

Author(s) :Katsueki Ogiwara, Takashi Ikeda and Takayuki Takahashi

Source: Zoological Science, 27(9):762-767. 2010.

Published By: Zoological Society of Japan

DOI: http://dx.doi.org/10.2108/zsj.27.762

URL: http://www.bioone.org/doi/full/10.2108/zsj.27.762

BioOne (www.bioone.org) is a nonprofit, online aggregation of core research in the biological, ecological, and environmental sciences. BioOne provides a sustainable online platform for over 170 journals and books published by nonprofit societies, associations, museums, institutions, and presses.

Your use of this PDF, the BioOne Web site, and all posted and associated content indicates your acceptance of BioOne's Terms of Use, available at www.bioone.org/page/terms_of_use.

Usage of BioOne content is strictly limited to personal, educational, and non-commercial use. Commercial inquiries or rights and permissions requests should be directed to the individual publisher as copyright holder. 


\title{
A New In Vitro Ovulation Model for Medaka Based on Whole Ovary Culture
}

\author{
Katsueki Ogiwara, Takashi Ikeda and Takayuki Takahashi* \\ Laboratory of Reproductive and Developmental Biology, Faculty of Science, \\ Hokkaido University, Sapporo 060-0810, Japan
}

\begin{abstract}
We sought to establish a new in vitro ovulation model using the whole ovaries of the medaka. Ovaries of the fish, which had been acclimated to the usual reproductive conditions $\left(26^{\circ} \mathrm{C}, 14 \mathrm{~h}\right.$ light/10 $\mathrm{h}$ dark) and which had then been kept at least one day at $30^{\circ} \mathrm{C}$, were isolated $2 \mathrm{~h}$ before the expected in vivo ovulation time. When the ovaries were cultured in $90 \%$ medium 199 solution at $30^{\circ} \mathrm{C}$ or $36^{\circ} \mathrm{C}$, oocytes were liberated with a gradual increase in the ovulation rate at 2 to $5 \mathrm{~h}$ of ovulation time. The maximum ovulation rate was $\sim 45 \%$. Ovulated oocytes were fertilized and subsequently developed into adults. In vitro ovulation of medaka ovaries was inhibited by the addition of metalloproteinase inhibitors to the culture. In this in vitro ovulation model, the holes formed on the follicle layer upon follicle rupture at ovulation were sealed, strongly suggesting the importance of the germinal epithelium in the process. The present study indicates that our new in vitro ovulation model is useful for investigating the role of germinal epithelial cells in the ovulate process of the medaka fish.
\end{abstract}

Key words: medaka, ovary, ovulation, new in vitro model, culture

\section{INTRODUCTION}

Oocytes grow in specialized tissues in vertebrate ovaries, called ovarian follicles, and are eventually liberated from the ovaries during ovulation. After ovulation, the follicular tissues that have released oocytes undergo postovulatory changes, eventually leading to tissue degradation. In mammals, the granulosa cells and some theca cells in the ovulated follicle form the corpus luteum (yellow body), but this temporary endocrine gland regresses thereafter (Stouffer, 2006). This series of events is a highly regulated, complex biological process that takes place under hormonal control involving gonadotropins.

To define the roles of the ovary, numerous studies have been conducted using a variety of methodological approaches. For example, in vitro follicle culture has proven useful for understanding the mechanisms underlying oocyte growth and differentiation in mammals. In view of clinical and agricultural interests, efforts have been made to develop culture systems using primordial follicles, because the follicles at this stage potentially represent a large source of oocytes in humans and large mammals (Eppig and O'Brien, 1996; Abir et al., 1999; Abir et al., 2001; Demeestere et al., 2002). While in vitro experimental systems suitable for studying follicular growth are available, only a handful of reports describing in vitro ovulation models in mammals have been published (Baranczuk and Fainstat, 1976; Brännström et al., 1987; Rose et al., 1999; Adam et al., 2004). This is probably due to the difficulty of setting stable conditions to obtain

\footnotetext{
* Corresponding author. Phone: $+81-11-706-2748$; Fax : +81-11-706-4851; E-mail: ttakaha@sci.hokudai.ac.jp
}

reproducible results.

The medaka Oryzias latipes is a small freshwater teleost that offers advantages for use in reproductive studies, including molecular mechanistic studies of ovulation. The fish usually spawns daily within $1 \mathrm{~h}$ of the onset of light for a number of consecutive days when maintained at ambient temperature $\left(26^{\circ} \mathrm{C}\right)$ under a constant long photoperiod of 14-h light and 10-h dark. Using this method, the sequence of events leading to spawning, such as completion of vitellogenesis, germinal vesicle breakdown and ovulation, can be timed accurately (Iwamatsu, 1978). Previous studies have elucidated the endocrinological background behind such reproductive events (Sakai et al., 1987; Sakai et al., 1988). In addition, the large follicles that are destined to ovulate on the next day are demonstrated to undergo a surge of gonadotropin at around 20-21 $\mathrm{h}$ before the expected time of ovulation (Iwamatsu, 1978). More advantageously, large follicles dissected from the ovary successfully ovulate under the in vitro conditions. This in vitro ovulation system allowed us to determine the hydrolytic enzymes responsible for follicle rupture during ovulation in the medaka (Ogiwara et al., 2005). However, the dissected, naked follicles in this system are freed from interaction with extracellular matrix molecules and devoid of the germinal epithelial cells, which are a constituent of the follicle wall in the ovarian follicle. Therefore, the in vitro ovulation model using dissected follicles may not be ideal for ovulation studies.

In the present study, we aimed to establish an in vitro ovulation system using a whole medaka ovary. We found that the fish ovary releases oocytes under appropriate organ culture conditions. To the best of our knowledge, this is the first report to elucidate an in vitro procedure to induce ovulation in the medaka. Compared with the in vitro ovulation model using dissected ovarian follicles, this new model 
could serve as a better experimental approach for ovulation studies of the medaka.

\section{MATERIAL AND METHODS}

\section{Animals}

Sexually mature medaka (body length $>20 \mathrm{~mm}$ ) were cultured at $26^{\circ} \mathrm{C}$ under a $14 \mathrm{~h}$ light $/ 10 \mathrm{~h}$ dark cycle. After the fish were acclimated to the conditions, mature female fish ovulated every day at the start of the light period. In this study, the start of the light period was designated as ovulation time 0 . The experimental procedures used in this study were approved by the Institutional Animal Use and Care Committee at Hokkaido University.

\section{In vitro ovulation using ovaries}

Ovaries of mature female medaka, which were acclimated to the reproductive conditions and ovulated daily at the onset of light, were obtained at $2 \mathrm{~h}$ before the expected time of ovulation and were placed in aseptic saline solution. The outermost thin layer, which wraps the ovary and separates it from the abdominal cavity, was quickly removed, and the resulting naked ovary was incubated in 90\% medium 199 solution (Earle's medium 199; Dainippon Seiyaku, Osaka, Japan) that had been previously adjusted to $\mathrm{pH} 7.4$ with $\mathrm{NaHCO}_{3}$. To assess in vitro ovulation, the ovary was incubated at $26^{\circ} \mathrm{C}, 30^{\circ} \mathrm{C}$, or $36^{\circ} \mathrm{C}$. The ovulation rate was defined as the percentage of ovulated follicles at a given time, with the assumption that large follicles (> $1.0 \mathrm{~mm}$ in diameter) in the isolated ovary would reliably ovulate.

\section{In vitro ovulation using dissected follicles}

In vitro ovulation experiments using follicles were conducted as previously described (Ogiwara et al., 2005). In brief, ovaries of mature female medaka were removed at $-3 \mathrm{~h}$ of ovulation and were placed in aseptic saline solution. The ovaries contained various sizes of follicles: small $(<0.5 \mathrm{~mm}$ in diameter, stages I-VI), medium (0.5-1.0 mm, stages VII-VIII), and large (> $1.0 \mathrm{~mm}$, stages IX-X) (Iwamatsu et al., 1988). Only the large follicles were immediately isolated, by using forceps under a dissecting microscope. The follicles collected in this way each consisted of one oocyte and surrounding follicle cells (granulosa cells and theca cells), but without the germinal epithelial cells. The large-sized follicles were transferred into $90 \%$ medium 199 solution. One culture dish usually contained at least 20 follicles. The $\mathrm{pH}$ of the culture medium was kept at 7.4 with $\mathrm{NaHCO}_{3}$. The follicles were cultured at $26^{\circ} \mathrm{C}$ in $4 \mathrm{ml}$ of culture medium using a $35 \times 10-\mathrm{mm}$ tissue-culture dish. The ovulation rate was defined as the percentage of ovulated follicles at a given time.

\section{In vitro fertilization}

Medaka oocytes ovulated under the organ culture conditions were used for in vitro fertilization. Oocytes released from the ovary during a $6-\mathrm{h}$ in vitro culture (-2 to $4 \mathrm{~h}$ ) in the same 199 solution were collected and placed in Iwamatsu's saline formulated for medaka oocytes (Iwamatsu, 1973). To the oocytes, testis homogenate prepared by a gentle homogenization in the same saline solution was added for fertilization. Fertilized oocytes were transferred to water and kept at $26^{\circ} \mathrm{C}$.

\section{Statistical analysis}

Data are presented as the mean or the mean \pm SEM of at least three independent experiments. Differences between groups were evaluated by Student's $t$-test, and values of $P<0.01$ were considered statistically significant.

\section{RESULTS}

\section{In vivo ovulation in the medaka}

Sexually mature medaka ovaries in vivo ovulated every

day at the start of the light period, which was set at $0 \mathrm{~h}$. Fig. 1 shows photographs of the fish ovary taken at $-3 \mathrm{~h}$ (Fig. 1A) and $0.5 \mathrm{~h}$ (Fig. 1B), together with their respective schematic drawings (Fig. 1, C and D). At $3 \mathrm{~h}$ before ovulation, the large follicles destined to ovulate still remained in the ovary (Fig. 1, A and C). At the time of ovulation (0.5 h), ovulated oocytes were present in the ovarian cavity (Fig. 1, B and $\mathrm{D}$ ). At this time point, almost all follicles (usually 20 to 30) destined to ovulate were ovulated.

\section{In vitro ovulation using the whole ovary of the medaka}

The in vivo ovulation was reproducibly observed at the time of ovulation in the ovary. As shown in Fig. 2, the release of oocytes from the ovary took place all at once at the time of ovulation. However, little or no ovulation was observed when the ovary was isolated from the medaka at $-2 \mathrm{~h}$ of ovulation and cultured at $26^{\circ} \mathrm{C}$. When follicles were dissected from the ovary for in vitro culture, they successfully ovulated. It took about $4 \mathrm{~h}$ in order for all follicles to complete ovulation, confirming our previous results (Ogiwara et al., 2005).

To our knowledge, no previous study has dealt with in vitro ovulation using the whole medaka ovary. In attempts to seek culture conditions for successful in vitro ovulation with the ovary, we found that exposure of females that had established $24-\mathrm{h}$ spawning cycles to $30^{\circ} \mathrm{C}$ for $24 \mathrm{~h}$ just prior

A
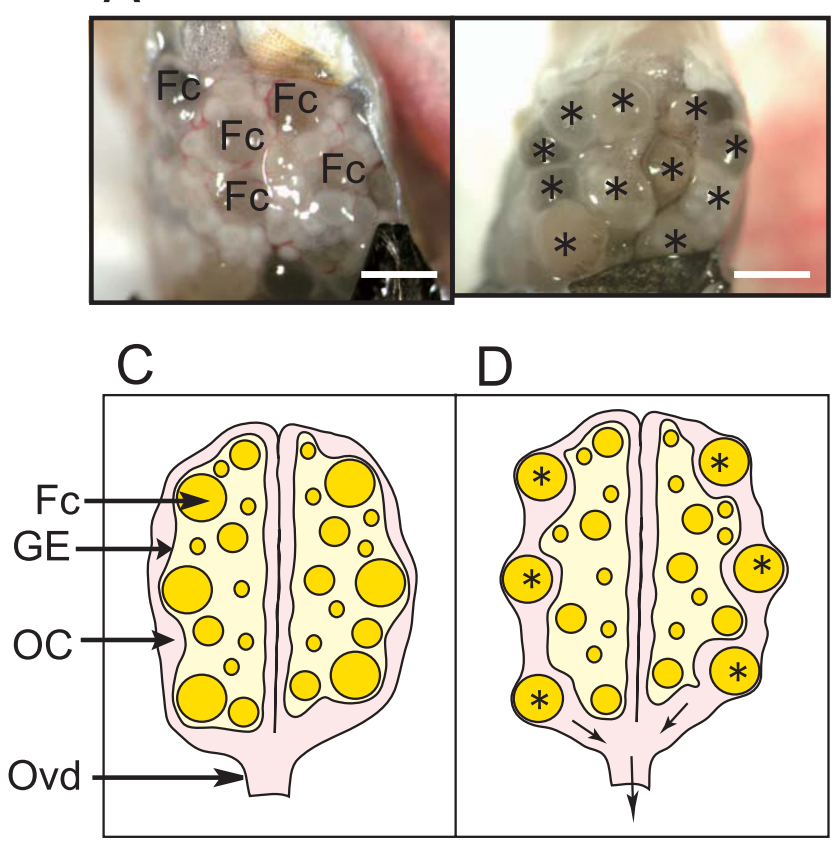

Fig. 1. Medaka ovary and ovulation. The ovary of mature medaka with a 24-h spawning cycle was observed at $3 \mathrm{~h}$ before the time of ovulation (A) or at $0.5 \mathrm{~h}$ after ovulation (B). In (A), all the follicles $(\mathrm{Fc})$ destined to ovulate were still in the ovary, but ovulated follicles (indicated by asterisks) were found in the ovarian cavity (OC) in (B). Panels (C) and (D) are illustrations of the ovary having unovulated follicles (corresponding to $A$ ) and ovulated follicles (corresponding to B), respectively. Ovd, oviduct; GE, germinal epithelium. Bars indicate $1 \mathrm{~mm}$. 
to sacrifice had some effect (Table 1). Using the ovaries isolated from the medaka thus pretreated, approximately $40 \%$ of the follicles liberated oocytes if the temperature of the in vitro ovary culture was raised from $26^{\circ} \mathrm{C}$ to $30^{\circ} \mathrm{C}$ or $36^{\circ} \mathrm{C}$. The addition of carp serum did not improve the rate of ovulation. Inclusion of divalent cations $\left(\mathrm{Ca}^{2+}\right.$ and $\left.\mathrm{Zn}^{2+}\right)$ was rather inhibitory for ovulation.

The time course of in vitro ovulation was examined using ovaries isolated from fish previously maintained for 1 day at $30^{\circ} \mathrm{C}$ (Fig. 3). In ovaries incubated in vitro at both $30^{\circ} \mathrm{C}$ and $36^{\circ} \mathrm{C}$, ovulated oocytes were observed at $2 \mathrm{~h}$ after

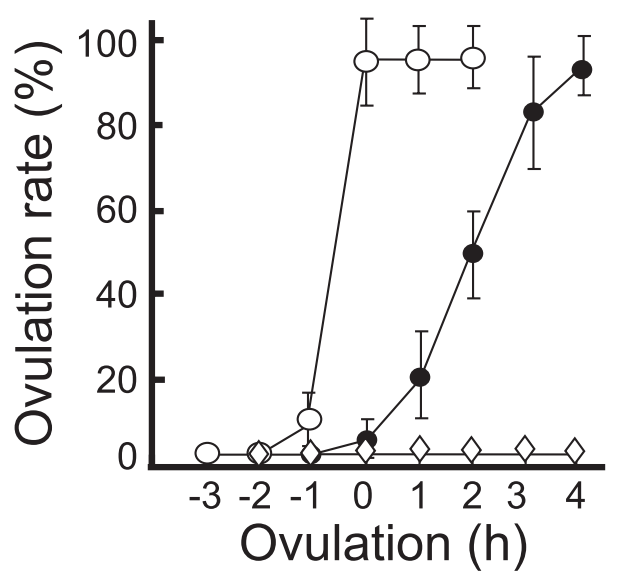

Fig. 2. In vivo ovulation of the medaka ovary. To assess the in vivo ovulation rate of the medaka, ovaries were isolated at the indicated time points from mature medaka fish with an established 24 h-reproductive ovulation cycle, and the ovulated oocytes present in the ovarian cavity were counted. The rate of ovulation is indicated by the percentage of ovulated oocytes to the total number of oocytes expected to be released from the ovary $(\bigcirc)$. Ovaries were isolated at $-2 \mathrm{~h}$ of ovulation from the mature medaka, and were cultured in medium 199 solution at $26^{\circ} \mathrm{C}$ for $6 \mathrm{~h}(\diamond)$. Ovarian follicles were isolated from the mature medaka ovaries at $-3 \mathrm{~h}$ of ovulation, and were cultured in medium 199 solution at $26^{\circ} \mathrm{C}$ for $7 \mathrm{~h}$ (O). Ovulated oocytes were counted at the indicated time points and the rate of ovulation was estimated. Each ovary had 20-30 oocytes destined for ovulation. The results shown are based on three independent experiments. Mean values \pm SEM are shown. Note that oocytes did not ovulate under the conditions routinely used in our laboratory for in vitro ovulation of dissected follicles. the expected time of ovulation. The rate of ovulation gradually increased thereafter to reach a maximum at $5 \mathrm{~h}$. A higher ovulation rate was consistently seen with the ovaries incubated at $36^{\circ} \mathrm{C}$ when compared with those incubated at $30^{\circ} \mathrm{C}$. The patterns of ovulation rates were different from those of in vivo ovulation, in which ovulation was apparently synchronized and completed in 60 min (Fig. 2). When ovaries were isolated from the medaka $2 \mathrm{~h}$ earlier than the expected ovulation time, in vitro ovulation was no longer observed. The unovulated oocytes stayed enclosed within follicles in the ovary even at $5 \mathrm{~h}$ after the expected time of ovulation.

It was observed that germinal vesicle breakdown in the oocytes of large-sized follicles occurred around $6 \mathrm{~h}$ before the expected time of ovulation, and this observation was consistent with a previous report (Iwamatsu, 1978). In Fig. 4 , photographs of the oocytes in the large-sized follicles are shown; the oocyte that just ovulated had completed germi-

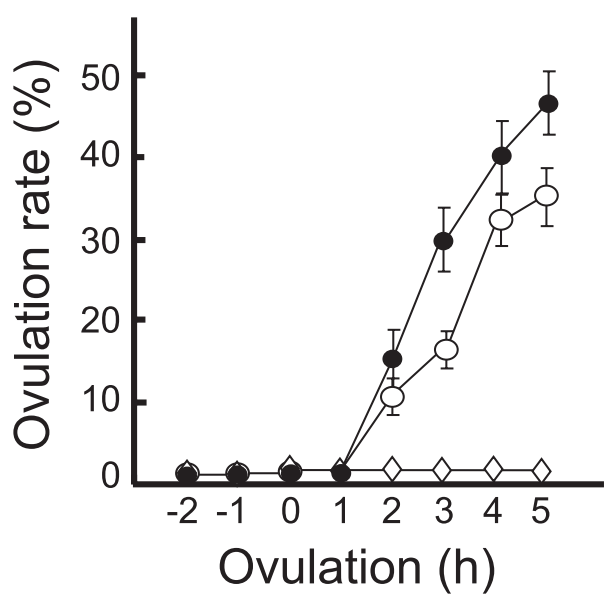

Fig. 3. Effects of in vitro culture temperatures on ovulation. Ovaries obtained at $-2 \mathrm{~h}$ of ovulation from mature medaka that had been maintained at $30^{\circ} \mathrm{C}$ for $24 \mathrm{~h}$, were incubated in medium 199 solution at $26^{\circ} \mathrm{C}(\diamond), 30^{\circ} \mathrm{C}(\bigcirc)$, or $36^{\circ} \mathrm{C}(\bullet)$. Each incubation contained a single ovary. At the indicated time points, ovulated oocytes were counted, and the rate of ovulation was determined. The number of oocytes destined for ovulation was $20-30$ per ovary. Mean values \pm SEM of four independent experiments are shown.

Table 1. In vitro ovulation using medaka ovaries.

\begin{tabular}{|c|c|c|c|c|c|c|}
\hline $\begin{array}{l}\text { Additives to the } \\
\text { in vitro culture }\end{array}$ & $\begin{array}{c}\text { No. of } \\
\text { experiments }\end{array}$ & $\begin{array}{c}\text { Conditions of animal } \\
\text { maintenance } \\
\text { (temperature and duration) }\end{array}$ & $\begin{array}{l}\text { Temperature of the } \\
\text { in vitro ovary culture }\end{array}$ & $\begin{array}{c}\text { Total No. of } \\
\text { follicles examined }\end{array}$ & $\begin{array}{c}\text { Total No. of } \\
\text { oocytes ovulated }\end{array}$ & $\begin{array}{c}\text { Ovulation rate } \\
\text { (\%) }\end{array}$ \\
\hline \multirow[t]{6}{*}{ None } & 2 & $26^{\circ} \mathrm{C}, 1$ day & $26^{\circ} \mathrm{C}$ & 39 & 1 & 3.0 \\
\hline & 2 & $26^{\circ} \mathrm{C}, 1$ day & $30^{\circ} \mathrm{C}$ & 40 & 2 & 5.0 \\
\hline & 2 & $26^{\circ} \mathrm{C}, 1$ day & $36^{\circ} \mathrm{C}$ & 51 & 4 & 8.0 \\
\hline & 6 & $30^{\circ} \mathrm{C}, 1$ day & $26^{\circ} \mathrm{C}$ & 142 & 19 & $13.4 \pm 2.4$ \\
\hline & 3 & $30^{\circ} \mathrm{C}, 1$ day & $30^{\circ} \mathrm{C}$ & 52 & 19 & $36.5 \pm 3.2$ \\
\hline & 3 & $30^{\circ} \mathrm{C}, 1$ day & $36^{\circ} \mathrm{C}$ & 71 & 31 & $43.7 \pm 5.6$ \\
\hline Carp serum (5\%) & 5 & $30^{\circ} \mathrm{C}, 1$ day & $36^{\circ} \mathrm{C}$ & 73 & 26 & $35.6 \pm 3.6$ \\
\hline \multicolumn{7}{|l|}{ Carp serum (5\%) } \\
\hline \multicolumn{7}{|l|}{$+\mathrm{Ca}^{2+}(5 \mathrm{mM})$} \\
\hline$+\mathrm{Zn}^{2+}(50 \mathrm{mM})$ & 2 & $30^{\circ} \mathrm{C}, 1$ day & $36^{\circ} \mathrm{C}$ & 43 & 8 & 18.5 \\
\hline
\end{tabular}


nal vesicle breakdown (Fig. 4B), while germinal vesicle was seen in the oocyte of the follicle at $-13 \mathrm{~h}$ of ovulation (Fig. $4 A)$.

The ovulated oocytes were estimated to be approximately $1 \mathrm{~mm}$ in diameter, indicating that only fully grown large follicles ovulated (Fig. 5).

\section{In vitro fertilization}

In vitro ovulated oocytes were all found to have completed the breakdown of the germinal vesicle. In order to check the quality of the in vitro ovulated oocytes, in vitro fertilization was conducted. Ovulated oocytes were fertilized and subsequently demonstrated the ability to develop into adults. In Fig. 4C, an IVF embryo at 4-cell stage is shown. We estimated the rate and the number of oocytes successfully fertilized to develop to the stage of hatching. Using three ovaries, 17 in vitro ovulated oocytes were obtained. After fertilization, 15 out of the 17 fertilized oocytes developed to the hatching stage. This high hatching rate $(88.2 \%)$ indicates the biological relevance of the present in vitro ovulation system.

\section{Usefulness of the current in vitro ovulation model using the whole ovary}

We examined the effects of matrix metalloproteinase (MMP) inhibitors on the medaka ovulation using our current ovary culture system. Incubation of ovaries in the culture medium containing MMP inhibitors, GM6001 and EDTA, resulted in the inhibition of ovulation (Fig. 6). These results are in agreement with those obtained with the in vitro culture model using dissected follicles (Ogiwara et al., 2005).

Postovulatory changes in the region of follicle rupture during ovulation were compared using the two in vitro ovulation systems. After ovulation, the sites of the rupture were sealed to recover a smooth surface of the ovary in the ovary culture system. On the other hand, in the in vitro ovulation of ovarian follicles dissected from the medaka ovary, a hole, through which the oocyte was released, remained open (data not shown). These observations strongly suggest that germinal epithelial cells play a critical role in the postovulatory tissue repair of the regionally disintegrated ovarian surface brought about by follicle rupture.

The results described above point to the usefulness of the current in vitro ovulation model to elucidate the molecular mechanism of the follicular tissue repair involving germinal epithelial cells at the site of ovulation that occurs soon after ovulation.

\section{DISCUSSION}

A merit of the medaka for ovulation studies is that it provides a simple in vitro experimental system using largesized ovarian follicles, each of which consists of a fully grown oocyte and a single layer each of granulosa and theca cells, with a basement membrane between the two layers. Indeed, the availability of this useful in vitro ovulation model allowed us to identify proteolytic enzymes critically
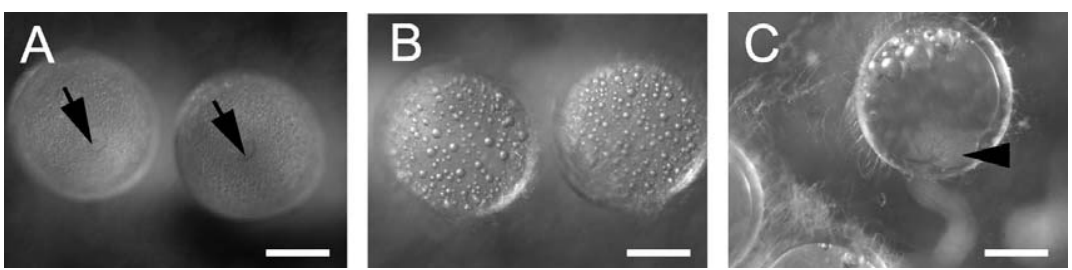

Fig. 4. Germinal vesicle breakdown and fertilization of ovulated oocytes. (A) Largesized follicles isolated from a mature fish ovary at $-13 \mathrm{~h}$ of ovulation were photographed. The germinal vesicles (indicated by arrows) were clearly observed in the oocytes. (B) Oocytes ovulated in the current in vitro ovary culture system were photographed soon after ovulation. No germinal vesicles were observed. (C) Oocytes ovulated in the current in vitro ovary culture system were fertilized, and the developing embryo (4-cell stage, indicated by arrowhead) was photographed. Bars indicate $500 \mu \mathrm{m}$.

A

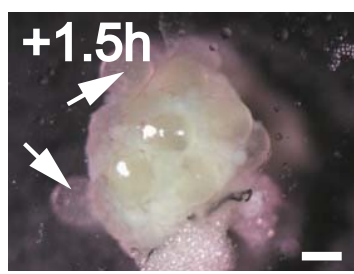

B
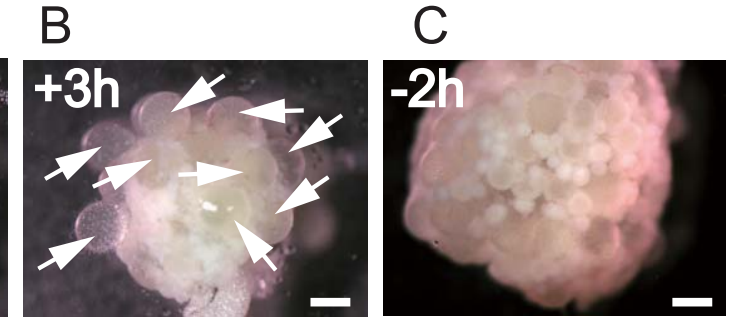

Fig. 5. In vitro ovulation using medaka ovaries. Ovaries were isolated at $-2 \mathrm{~h}$ of ovulation and incubated at $36^{\circ} \mathrm{C}$ in the medium. Photographs were taken at $1.5 \mathrm{~h}(\mathbf{A})$ and $3 \mathrm{~h}$ (B). Note that ovulated oocytes (white arrows) were attached to the ovary in (A) and (B). A photograph of the isolated ovary was taken at $-2 \mathrm{~h}$ of ovulation (C). Bars indicate $1 \mathrm{~mm}$.

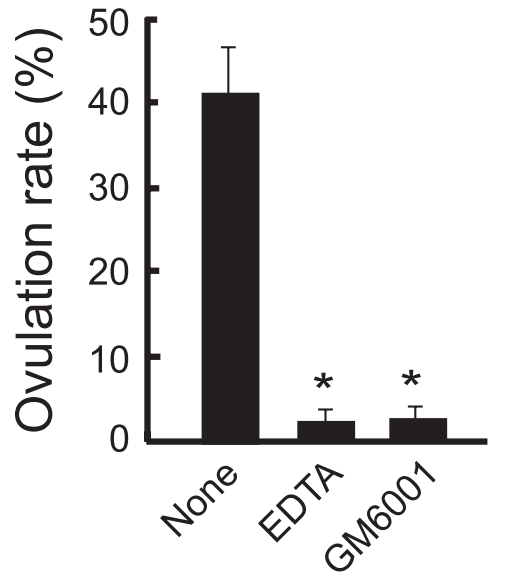

Fig. 6. Effects of MMP inhibitors on ovulation. The ovaries were isolated at $-2 \mathrm{~h}$ of the expected ovulation time from mature medaka, and were separately incubated in the medium containing MMP inhibitors, EDTA (2 mM, final concentration) and GM6001 (10 $\mu \mathrm{M}$, final concentration). The rate of ovulation in each culture was determined at $4 \mathrm{~h}$ after the time of ovulation. Controls were the ovary cultures without inhibitors. Each experiment was conducted using a single ovary, and the results are based on three independent experiments. The actual and expected numbers of ovulated oocytes were 9 out of 24, 9 out of 22 , and 14 out of 29 for the control. These numbers were 2 out of 27, 0 out of 20, and 0 out of 25 for EDTA, and 0 out of 21,2 out of 22 , and 0 out of 28 for GM6001, respectively. The mean values \pm SEM are shown. An asterisk indicates a significant difference from the control at $P<0.01$. 
involved in follicle rupture during ovulation in the medaka (Ogiwara et al., 2005). However, the dissected follicles used in the model are naked and not in contact with the germinal epithelial cells. Therefore, it is reasonable to conclude that the previous ovulation model is not suitable for further clarification of the in vivo mechanism of ovulation. For this reason, the current ovulation model using the whole ovary of the fish was developed.

Since the female medaka ovulates 20-30 oocytes every day under the usual maintenance conditions $\left(26^{\circ} \mathrm{C}\right)$, we initially expected that ovulation would readily occur in cultured ovaries. Surprisingly, however, the ovaries did not ovulate at $26^{\circ} \mathrm{C}$ in vitro at all. Because naked follicles isolated from the ovaries of the fish maintained under the same conditions successfully ovulated in vitro at an ovulation rate of more than $90 \%$ (Ogiwara et al., 2005), this finding strongly suggests that the germinal epithelial cells place obstacles to prevent follicle rupture when cultured ovaries are used. We are uncertain why the ovary failed to ovulate when it was transferred to the in vitro culture conditions. It is worth noting here, however, a number of previous studies addressing the involvement of the surface epithelium in the ovulatory process in mammals (Espey, 1967; Parr, 1975; Motta and van Blerkom, 1975; Rawson and Espey, 1977). Generally, the results of these studies argue against the idea that the germinal epithelial cells covering the entire surface of the ovary play an essential role in ovulation (Espey and Richards, 2006).

For in vitro ovulation using the medaka ovaries, increased temperatures of both animal maintenance and in vitro organ culture were found to be effective. Raising the maintenance temperature to $30^{\circ} \mathrm{C}$, a physiological temperature for the fish, followed by culturing the ovary at the same temperature, resulted in a successful ovulation. However, in that in vitro ovulation model, the rate of ovulation was approximately $40-45 \%$ at best. Obviously, further improvement in the ovulation rate of this model is needed. Nevertheless, the current in vitro ovulation model using the whole ovary is the first to provide an additional in vitro procedure for investigating the ovulatory process of the fish. The biological relevance of our present model to studies of ovulation was supported by the results of the in vitro fertilization assay of ovulated oocytes. In addition, the ovulation inhibition test using various protease inhibitors in the ovulation model produced basically the same results as obtained by an in vitro model using dissected follicles (Ogiwara et al., 2005).

Our data indicate that the maintenance of the medaka at $30^{\circ} \mathrm{C}$ for at least one day prior to the ovary culture was important for successful in vitro follicle rupture. It is not clear at the present time why exposure of the fish to a temperature of $30^{\circ} \mathrm{C}$ was critical. It may be that pretreatment of the fish at $30^{\circ} \mathrm{C}$ induces the synthesis of proteins, including proteolytic enzymes necessary for follicle rupture, at greater levels than under the normal reproductive conditions $\left(26^{\circ} \mathrm{C}\right)$. Such increased production of proteins might enable the isolated ovary to ovulate in vitro at $30^{\circ} \mathrm{C}$. Since the rupture has been shown to be accomplished by the concerted actions of at least three MMPs in the medaka (Ogiwara et al., 2005), we suggest that these MMPs are reasonable candidates for the proteins putatively induced by the temperature treat- ment. One may speculate that raising the temperature from $26^{\circ} \mathrm{C}$ to $30^{\circ} \mathrm{C}$ in the ovary culture alone is effective for in vitro ovulation. However, this idea is not supported by our observation that ovaries isolated from the medaka previously kept at a constant temperature of $26^{\circ} \mathrm{C}$ did not ovulate at all, even when cultured at $30^{\circ} \mathrm{C}$.

The present study revealed a clear distinction in postovulatory follicles in the two ovulation models, using either dissected follicles or ovaries. After the ovary liberated oocytes in vitro, the ruptured region on the germinal epithelium of the ovary was found to be closed. In contrast, in the follicles that were subjected to in vitro ovulation, the ruptured areas were always kept open and never sealed. This difference seems to depend on whether or not the germinal epithelial cells are present. We hypothesize that the epithelium plays an important role in the repair process of follicles that have just ovulated. Consistent with this hypothesis, no detectable hole was observed at any time on the germinal epithelium of medaka ovary that had ovulated in vivo. We are convinced that the current in vitro model will help to clarify the contribution of germinal epithelial cells to the postovulatory tissue repair process in the fish.

In summary, we have developed a novel in vitro ovulation model for the medaka ovary. To the best of our knowledge, this is the first report of the establishment of a new ovulation model based on ovary culture for a non-mammalian species. The current model would be useful for examining the process of ovulation in detail. In particular, the roles of the germinal epithelial cells in the follicle rupture and postovulatory tissue repair processes in ovulation can be examined using this novel experimental model.

\section{ACKNOWLEDGMENTS}

This study was supported in part by a Grant-in-Aid for Scientific Research from the Ministry of Education, Culture, Sports, Science, and Technology of Japan.

\section{REFERENCES}

Abir R, Roizman P, Fisch B, Nitke S, Okon E, Orvieto R, Ben Rafael $Z$ (1999) Pilot study of isolated early human follicles cultured in collagen gels for 24 hours. Hum Reprod 14: 1299-1301

Abir R, Fisch B, Nitke S, Okon E, Raz A, Ben Rafael A (2001) Morphological study of fully and partially isolated early human follicles. Fertil Steril 75: 141-146

Adam AAG, Takahashi Y, Katagiri S, Nagano M (2004) In vitro culture of mouse preantral follicles using membrane inserts and developmental competence of in vitro ovulated oocytes. J Reprod Dev 50: 579-586

Baranczuk RJ, Fainstat T (1976) In vitro ovulation from adult hamster ovary. Am J Obstet Gynecol 124: 517-522

Brännström M, Koos RD, Le Maire WJ, Janson PO (1987) Cyclic adenosine 3',5'-monophosphate-induced ovulation in the perfused rat ovary and its mediation by prostaglandins. Biol Reprod 37: 1047-1053

Demeestere I, Delbaere A, Gervy C, van den Bergh M, Devreker F, Englert $Y$ (2002) Effect of preantral follicle isolation technique on in-vitro follicular growth, oocyte maturation and embryo development in mice. Hum Reprod 17: 2152-2159

Eppig JJ, O'Brien MJ (1996) Development in vitro of mouse oocytes from primordial follicles. Biol Reprod 54: 197-207

Espey LL (1967) Ultrastructure of the apex of the rabbit graafian follicle during the ovulatory process. Endocrinology 81: 267-276

Espey LL, Richards JS (2006) Ovulation. In "Physiology of Repro- 
duction, Vol 1" $3^{\text {rd }}$ ed Ed by JD Neil et al., Academic Press, Amsterdam, pp 425-474

Iwamatsu T (1973) Studies on oocyte maturation in the medaka, Oryzias latipes. Improvement of culture medium for oocyte in vitro. Jpn J Ichthyol 20: 218-224

Iwamatsu T (1978) Studies on oocyte maturation of the medaka, Oryzias latipes. VI. Relationship between the circadian cycle of oocyte maturation and activity of the pituitary gland. J Exp Zool 206: 355-364

Iwamatsu T, Ohta T, Oshima E, Sakai N (1988) Oogenesis in the medaka Oryzias latipes. Stages of oocyte development. Zool Sci 5: 353-373

Motta P, van Blerkom J (1975) A scanning electron microscopic study of the luteo-follicular complex. II. Events leading to ovulation. Am J Anat 143: 241-263

Ogiwara K, Takano N, Shinohara M, Murakami M, Takahashi T (2005) Gelatinase A and membrane-type matrix metalloproteinases 1 and 2 are responsible for follicle rupture during ovulation in the medaka. Proc Natl Acad Sci USA 102: 8442-8447

Parr EL (1975) Rupture of ovarian follicles at ovulation. J Reprod
Fertil Suppl 22: 1-22

Rawson JM, Espey LL (1977) Concentration of electron dense granules in the rabbit ovarian surface epithelium during ovulation. Biol Reprod 17: 561-566

Rose UM, Hanssen RG, Kloosterboer HJ (1999) Development and characterization of an in vitro ovulation model using mouse ovarian follicles. Biol Reprod 61: 503-511

Sakai N, Iwamatsu T, Yamauchi K, Nagahama T (1987) Development of the steroidogenic capacity of medaka (Oryzias latipes) ovarian follicles during vitellogenesis and oocyte maturation. Gen Comp Endocrinol 66: 333-342

Sakai N, Iwamatsu T, Yamauchi K, Suzuki N, Nagahama T (1988) Influence of follicular development on steroid production in the medaka (Oryzias latipes) ovarian follicle in response to exogenous substrates. Gen Comp Endocrinol 71: 516-523

Stouffer RL (2006) Structure, function, and regulation of the corpus luteum. In "Physiology of Reproduction, Vol 1" $3^{\text {rd }}$ ed Ed by JD Neill et al., Academic Press, Amsterdam, pp 475-526

(Received February 1, 2010 / Accepted April 13, 2010) 